Proceeding Paper

\title{
Assessment of Carbon Sequestration Potential of Tree Species in Amity University Campus Noida ${ }^{\dagger}$
}

\author{
Richa Sharma ${ }^{1, *}$, Lolita Pradhan ${ }^{1}$, Maya Kumari ${ }^{1}$ and Prodyut Bhattacharya ${ }^{2}$ \\ 1 Amity School of Natural Resources \& Sustainable Development, Amity University, Sector 125, Noida, \\ Uttar Pradesh 201301, India; pradhanlolita2013@gmail.com (L.P.); maya.84s@gmail.com (M.K.) \\ 2 School of Environmental Management, Block 'A', Guru Gobind Singh Indraprastha University, \\ New Delhi 110078, India; prodyutbhattacharya@yahoo.com \\ * Correspondence: richasharma1987@gmail.com; Tel.: +91-999-908-1539 \\ + Presented at the 1st International Electronic Conference on Forests - Forests for a Better Future: Sustainabil- \\ ity, Innovation, Interdisciplinarity, 15-30 November 2020; Available online: https://iecf2020.sciforum.net.
}

Citation: Sharma, R.; Pradhan, L.; Kumari, M.; Bhattacharya, P. Assessment of Carbon Sequestration Potential of Tree Species in Amity University Campus Noida. Environ. Sci. Proc. 2021, 3, 52. https://doi.org/ 10.3390/IECF2020-08075

Academic Editors: Angela Lo Monaco, Cate Macinnis-Ng and Om P. Rajora

Published: 13 November 2020

Publisher's Note: MDPI stays neutral with regard to jurisdictional claims in published maps and institutional affiliations.

Copyright: (C) 2020 by the authors. Licensee MDPI, Basel, Switzerland. This article is an open access article distributed under the terms and conditions of the Creative Commons Attribution (CC BY) license (http://creativecommons.org/licenses/by/4.0/).

\begin{abstract}
Urban green spaces, particularly trees, have great potential to sequester carbon from the atmosphere and mitigate the impacts of climate change in cities. Large university campuses offer prominent space where such green spaces can be developed in order to offset the increasing greenhouse gas emissions, as well as other benefits. Amity University, Noida, is spread over 60 acres with dense tree plantations in and around the campus. The present study is a sustainability initiative to inventory the tree species on the campus and assess their total carbon sequestration potential (CSP). The above- and below-ground biomasses were estimated using the non-destructive sampling method. Individual trees on the campus were measured for their height and diameter at breast height $(\mathrm{DBH})$, and estimates of carbon storage were performed using allometric equations. There is a total of 45 different tree species on the campus with the total CSP equivalent to approximately 139.86 tons. The results also reveal that Ficus benjamina was the predominant species on the campus with CSP equivalent to 30.53 tons, followed by Alstonia scholaris with carbon storage of 16.38 tons. The study reports that the ratio of native to exotic species is 22:23 or almost 1:1. The present work highlights the role of urban forests or urban green spaces, not only as ornamental and aesthetic plantations but also in mitigating the impacts of climate change at a local level. Higher education institutes have an important role in expanding their green cover so as to act as local carbon sinks.
\end{abstract}

Keywords: above-ground biomass (AGB); below-ground biomass (BGB); carbon sequestration potential (CSP); urban forests

\section{Introduction}

Cities are the hubs of economic growth and development. Urban areas contribute close to half of India's gross domestic product today, but the rapid urbanization is a major driver of global change, driving land use change, habitat loss, biodiversity decline, climate change, and pollution both within and outside the city [1]. A report published by International Council of Local Environmental Initiatives (ICLEI), South Asia, has stated that average per capita carbon emissions are higher in the metropolitan cities of India, being 1.19 tons per capita, as compared to only 0.90 tons per capita in the non-metropolitan cities. Reduction in carbon dioxide concentrations in the atmosphere can be achieved either by reducing the demand for energy, altering the usage of energy or increasing the rates of removal of $\mathrm{CO}_{2}$ through the trees through carbon sequestration, which can decrease the atmospheric carbon dioxide naturally [2].

The term urban forest and urban green space includes trees in gardens, parks, and along the streets, roads, canal, etc., which contribute to verdancy in the city [3]. These spaces provide a variety of ecosystem services such as improving air quality [4], buffering 
of noise pollution, biodiversity conservation, mitigating Urban Heat Island effect, microclimate regulation, stabilization of soil, ground water recharge, prevention of soil erosion, and carbon sequestration [5]. Studies conducted by several scientists have claimed that urban green spaces can play a very important role in limiting the city's carbon footprint [6]. The vegetation and soil of a greenspace cannot only sequester carbon, directly contributing to a reduction in atmospheric $\mathrm{CO}_{2}$ concentration, but also affect the carbon balance indirectly, through their effects on the urban energy balance and thus on $\mathrm{CO}_{2}$ emissions related to energy use [7]. In addition, these upgrade the standards of urban living by facilitating the health and well-being of the people by alleviating stress and enabling relaxation. Such areas also deliver an array of cultural services such as spiritual and religious, recreation, ecotourism and aesthetics [8]. The maximum benefit of these spaces largely depends on judicious selection of an appropriate and diverse mix of tree species and their proper management in the urban areas $[9,10]$.

According to the Intergovernmental Panel on Climate Change (2006), the major five carbon pools of a terrestrial ecosystem involving biomass are above-ground biomass, below-ground biomass, dead wood, litter and soil organic matter [11]. Therefore, there are three ways in which urban green spaces can repress atmospheric carbon. Firstly, autotrophs take up carbon dioxide from the atmosphere-a part of which is released back into the atmosphere and the remainder is stored in the plant tissues above and below ground, resulting in the plant growth in the form of biomass. Therefore, all autotrophs convert atmospheric carbon dioxide into biomass, but trees, specifically, are considered to be the major sinks or sponges of carbon. The carbon assimilated by trees is retained for longer duration with little leakage into the atmosphere. Annual rates of carbon sequestration largely depend on the tree size at maturity, life span and their growth rates [12]. After the trees die, the biomass either enters the food chain or the soil as soil carbon [13]. Secondly, the soils are also chief contributors to the carbon stocks. Litter and woody debris are not a major carbon pool as they contribute only a small fraction to the total carbon stocks. Thirdly, urban vegetation reduces the demand for cooling the building by providing shade and evapotranspiration, and demand for heating living spaces by reducing wind speed. This substantially reduces burden on fossil fuel burning for electricity generation, thus offsetting carbon emissions [14].

Though the importance of forested areas in carbon sequestration has been well established and documented, few attempts have been made to address the potential of trees in carbon sequestration in urban cities. It is important to study the carbon sequestration potential of urban centers so as to understand and highlight the role of urban green spaces in offsetting carbon emissions at a local level. Large university campuses provide large areas for urban tree plantations that can be a potential solution for climate change mitigation. Being aware of how much carbon an urban green space can sequester is helpful because it can help an institution or organization offset its emissions and value its green spaces.

There are a number of studies wherein carbon stock estimation is performed for University campuses in India. Gavali and Shaikh (2016) estimated tree biomass and carbon storage in the Solapur University of Maharastra and reported that urban green spaces are likely to have a wider impact per area of tree canopy cover in comparison to other nonurban forests due to faster growth rates and increased proportions of large trees [15]. Marak and Khare (2017) also estimated carbon sequestration potential of tree species in the Sam Higginbottom University of Agriculture, Technology and Sciences (SHUATS) campus, Allahabad, and identified the important species with maximum carbon sequestration potential [16]. Similar studies on carbon sequestration have been carried out in Jnanabharathi campus, Bangalore University [17], Bharathiar University campus at Coimbatore [18], Andhra University, Vishakhapatnam [19], North Maharashtra University Campus, Jalgaon [13], Golapbag campus of Burdwan University [20,21], various educational institutes in Vijaypur, Jammu and Kashmir [22] and Vellore Institute of Technology (VIT) campus [23]. However, a complete and recent analysis of CSP of Amity University 
Noida campus has not yet been performed. Therefore, the main objective of the present work is to inventory the tree species present on the campus and calculate their total carbon sequestration potential.

\section{Study Area}

The present work was carried out in Amity University campus, located in Noida, Uttar Pradesh (Figure 1). The campus is spread over 60 acres with dense tree plantations in and around it. The total geographic area of the campus is 24 hectares. It is well connected to the national capital and is located on the Yamuna Expressway, connecting Greater Noida. The campus is divided into academic and administrative blocks, interspersed with plenty of green spaces.

The city experiences cold winters and warm summers, with a temperature ranging from a maximum of $48^{\circ} \mathrm{C}$ to a minimum of $28^{\circ} \mathrm{C}$. It receives very little rainfall throughout the year with an average of around $728 \mathrm{~mm}$ per year. The city has witnessed extensive urbanization throughout the years, with a number of high-rise buildings, corporations and industries [24].

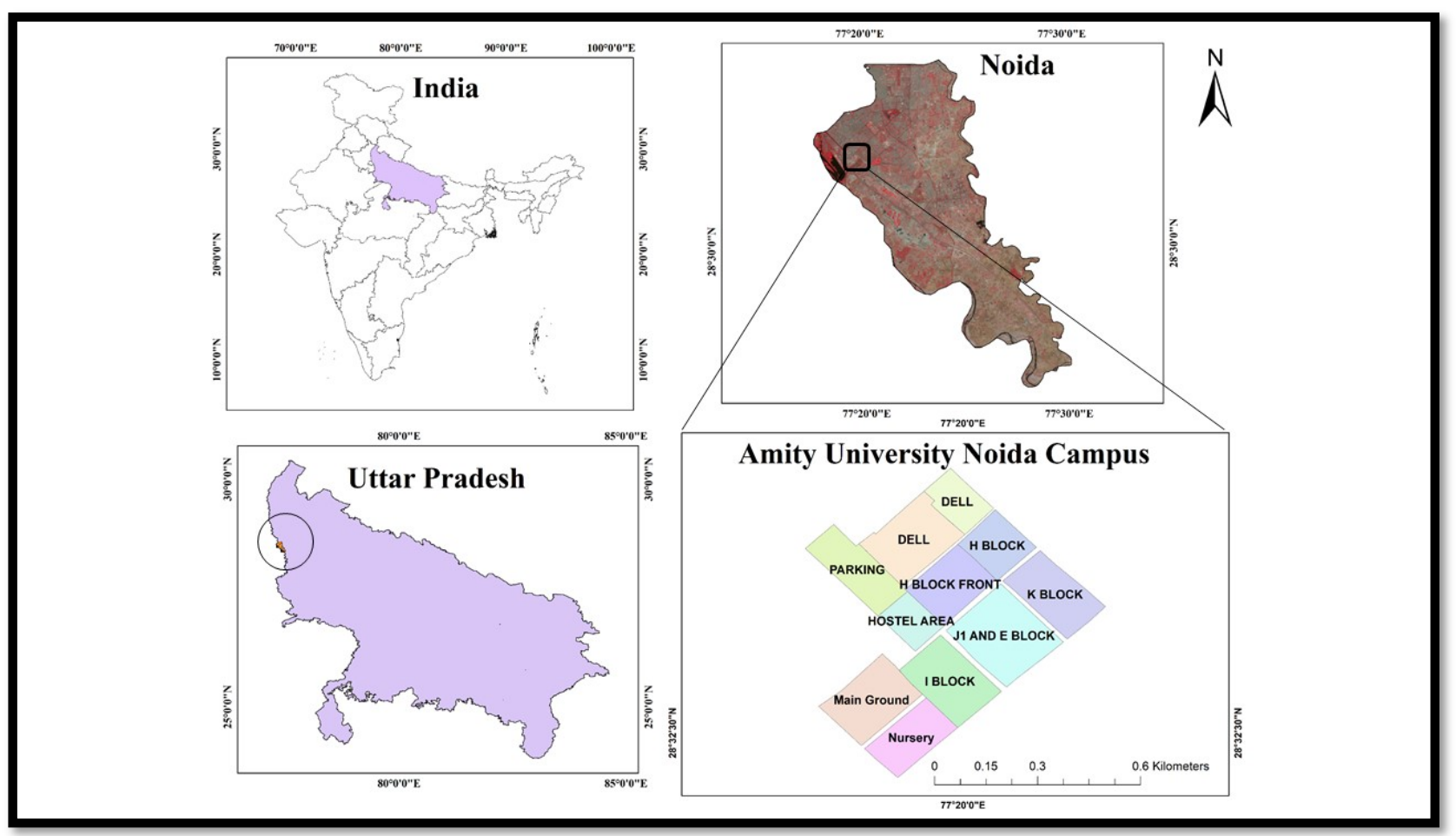

Figure 1. Study area.

\section{Material and Methods}

\subsection{Tree Cover Mapping}

Between March 2019 and March 2020, complete enumeration of the 1997 trees on the campus was performed block-wise (Figure 2).

\subsection{Tree Height and Girth at Breast Height (GBH)}

A non-destructive method of biomass estimation was used to measure the tree height and GBH of individual trees of the campus. Individual trees greater than or equal to 30 $\mathrm{cm}$ in girth at breast height $(1.37 \mathrm{~m})$ were enumerated. Tree height and girth were measured using clinometer/altimeter and measuring tape, respectively. Field data were recorded in spreadsheets. Species level identification of trees was obtained through visual 
observation, and the doubtful samples were collected and stored in herbarium for later identification by taxonomists. Shrubs and herbs were not recorded.

\subsection{Estimation of Above-Ground and Below-Ground Biomass (AGB and BGB)}

Above-ground and below-ground biomasses were estimated on the basis of field measurements of diameter at breast height $(\mathrm{DBH})$ of the tree using allometric equations [25]. The below given equation is applicable to dry climates with annual rainfall $<1500$ $\mathrm{mm}$; hence, it can be used for Noida where the average annual rainfall ranges between 700 and $800 \mathrm{~mm}$.

$$
\mathrm{AGB}=34.4703-8.0671 \mathrm{D}+0.6589 \mathrm{D}^{2}
$$

where $\mathrm{D}$ is the $\mathrm{DBH}(\mathrm{cm})$.

$$
\mathrm{BGB}=\mathrm{AGB} \times(15 / 100)
$$

\subsection{Estimation of Total Biomass (TB)}

Total biomass of individual trees will be the sum of their above- and below-ground biomasses, respectively, given by the following equation:

$$
\text { Total Biomass }=\mathrm{AGB}+\mathrm{BGB}
$$

\subsection{Estimation of Carbon Content}

Generally, for any plant species, $50 \%$ of its biomass is its carbon content [11].

$$
\text { Carbon Content }=0.5 \times \text { Total Biomass }
$$

$\mathrm{CO}_{2}$ equivalent is then calculated using the below given equation:

$$
\mathrm{CO}_{2} \text { (eq.) }=(\text { Carbon content } \times 44) / 12
$$

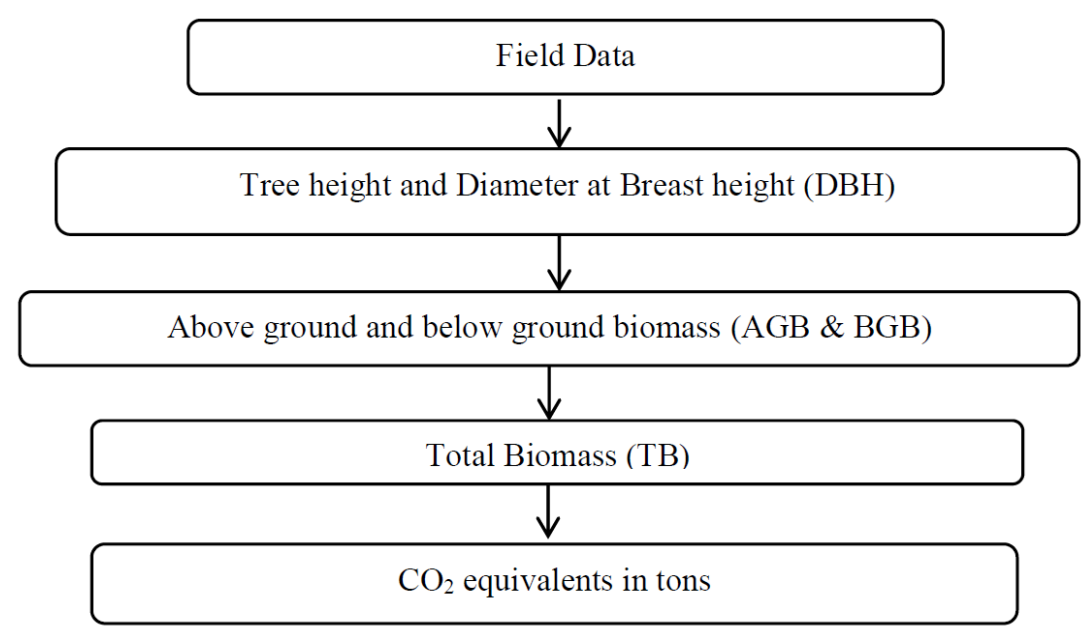

Figure 2. Methodology flowchart.

\section{Results and Discussion}

A total of forty-five different species of trees were enumerated on the campus (Figure 3 , Table 1). The most dominant species on the campus is Ficus benjamina, with a total of 436 trees. This species is commonly used in urban plantations as it is shade tolerant, can survive drought conditions, requires very little maintenance and can thrive in a range of soil types. Its ability to regenerate by aerial roots, cuttings and by seeds, as well as its dense canopy cover that provides shade, makes it an ideal choice for avenue plantations. 
One of the disadvantages of this non-native tree species is that its vigorous and invasive root system buckles up pavements and roads [26].

The second and the third most common tree species are Alstonia scholaris and Plumeria obtusa, with their individual tree number equal to 308 and 222, respectively. Alstonia scholaris, also known as the Devil's tree or the Blackboard tree, is prominently used in urban plantations because of its ability to survive dry conditions, hardy nature, and tolerance against air pollution [27]. It is the most common native tree species found on the campus. Plumeria obtusa also has evolved to be one of the most preferred ornamental trees in urban areas, as it requires little or no maintenance, can propagate easily and looks magnificent with beautiful clusters of flowers all year round [28]. Delonix regia and Neolamarckia cadamba also have over a hundred tree plantations on the campus.

The ratio of native to non-native species on the campus is approximately 1:1. The largest DBH is recorded for a Ficus religiosa tree measuring $298.7 \mathrm{~cm}$, followed by Bombax ceiba and Morus rubra trees measuring 265.1 and $213.3 \mathrm{~cm}$, respectively. The above-ground biomass (AGB) and below-ground biomass (BGB) of all the trees of the campus are equivalent to $63,136.8$ and $9470.5 \mathrm{~kg}$, respectively. The total biomass accumulated is $72,607.3 \mathrm{~kg}$ and the total carbon content of the campus trees is equal to $38,142.5 \mathrm{~kg}$. The total carbon sequestered by all the trees in a year is 139.9 tons. In other words, on average, carbon sequestered by an individual tree on the campus is $70 \mathrm{~kg}$ or 0.07 tons. A similar study performed in California State University, Northridge (CSUN), reveals that the total carbon dioxide sequestered by campus trees was in the order of 154 tons per year [29]. Haghparast (2013) also reported a total of 1694.5 tons of sequestrated carbon for seventysix plots of Pune University campus [30]. Analysis of CSP of New Zealand University gave the estimates that 4139 trees stored 5809 tons of $\mathrm{CO}_{2}$ [31].

\section{Annual $\mathrm{CO}_{2}$ sequestered by tree species}

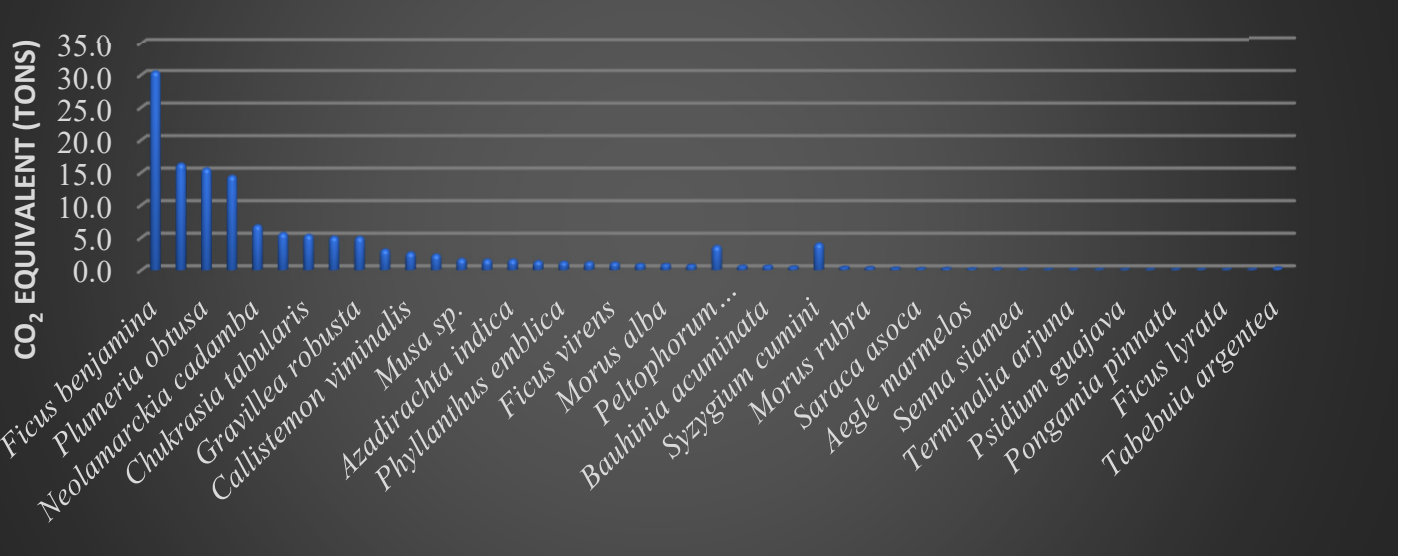

Figure 3. Annual $\mathrm{CO}_{2}$ sequestered by different tree species in the campus. 
Table 1. $\mathrm{CO}_{2}$ Eq. (tons) of tree species in Amity University Campus.

\begin{tabular}{|c|c|c|c|c|c|c|c|c|c|c|}
\hline \multirow{2}{*}{ S.N. } & \multicolumn{2}{|c|}{ Species Name } & \multirow{2}{*}{$\begin{array}{c}\text { Native/ } \\
\text { Exotic Species }\end{array}$} & \multirow{2}{*}{$\begin{array}{c}\text { Total No. } \\
\text { of Trees }\end{array}$} & \multirow{2}{*}{$\begin{array}{c}\text { AGB } \\
(\mathrm{kg})\end{array}$} & \multirow{2}{*}{$\begin{array}{c}\text { BGB } \\
(\mathrm{kg})\end{array}$} & \multirow{2}{*}{$\begin{array}{l}\text { TB } \\
(\mathrm{kg})\end{array}$} & \multirow{2}{*}{$\begin{array}{c}\text { Carbon } \\
(\mathrm{kg})\end{array}$} & \multirow{2}{*}{$\begin{array}{c}\mathrm{CO}_{2} \mathrm{EQ} \\
(\mathrm{kg})\end{array}$} & \multirow{2}{*}{$\begin{array}{c}\mathrm{CO}_{2} \mathrm{EQ} . \\
\text { (tons) }\end{array}$} \\
\hline & Scientific Name & Common Name & & & & & & & & \\
\hline 1 & Ficus benjamina & Weeping fig & Exotic & 436 & $14,481.29$ & 2172.19 & $16,653.48$ & 8326.74 & $30,531.39$ & 30.53 \\
\hline 2 & Alstonia scholaris & Scholar's Tree & Native & 308 & 7769.11 & 1165.37 & 8934.48 & 4467.24 & $16,379.87$ & 16.38 \\
\hline 3 & Plumeria obtusa & White Frangipani & Exotic & 222 & 7420.95 & 1113.14 & 8534.09 & 4267.04 & $15,645.83$ & 15.65 \\
\hline 4 & Delonix regia & Flame Tree & Exotic & 211 & 6883.30 & 1032.50 & 7915.80 & 3957.90 & $14,512.30$ & 14.51 \\
\hline 5 & Neolamarckia cadamba & Kadam & Native & 100 & 3274.72 & 491.21 & 3765.92 & 1882.96 & 6904.19 & 6.90 \\
\hline 6 & Ficus microcarpa & Laurel fig & Native & 82 & 2716.93 & 407.54 & 3124.47 & 1562.24 & 5728.20 & 5.73 \\
\hline 7 & Chukrasia tabularis & Indian Mahogany & Native & 78 & 2578.00 & 386.70 & 2964.70 & 1482.35 & 5435.28 & 5.44 \\
\hline 8 & Phoenix dactylifera & Date Palm & Exotic & 77 & 2451.74 & 367.76 & 2819.50 & 1409.75 & 5169.09 & 5.17 \\
\hline 9 & Gravillea robusta & Silver Oak & Exotic & 74 & 2430.46 & 364.57 & 2795.03 & 1397.51 & 5124.21 & 5.12 \\
\hline 10 & Roystonea regia & Royal Palm & Exotic & 46 & 1515.21 & 227.28 & 1742.50 & 871.25 & 3194.58 & 3.19 \\
\hline 11 & Callistemon viminalis & Bottlebrush tree & Exotic & 39 & 1303.96 & 195.59 & 1499.55 & 749.78 & 2749.18 & 2.75 \\
\hline 12 & Eucalyptus sp. & Eucalyptus & Exotic & 36 & 1155.93 & 173.39 & 1329.32 & 664.66 & 2437.09 & 2.44 \\
\hline 13 & Musa sp. & Banana & Exotic & 25 & 835.56 & 125.33 & 960.90 & 480.45 & 1761.64 & 1.76 \\
\hline 14 & Mimusops elengi & Spanish Cherry & Native & 24 & 791.78 & 118.77 & 910.55 & 455.27 & 1669.34 & 1.67 \\
\hline 15 & Azadirachta indica & Neem & Native & 24 & 784.78 & 117.72 & 902.50 & 451.25 & 1654.58 & 1.65 \\
\hline 16 & Cassia fistula & Indian Laburnum & Native & 20 & 670.61 & 100.59 & 771.21 & 385.60 & 1413.88 & 1.41 \\
\hline 17 & Phyllanthus emblica & Indian Gooseberry & Native & 19 & 615.51 & 92.33 & 707.84 & 353.92 & 1297.70 & 1.30 \\
\hline 18 & Dalbergia sissoo & Indian Rosewood & Native & 18 & 592.21 & 88.83 & 681.04 & 340.52 & 1248.58 & 1.25 \\
\hline 19 & Ficus virens & White Fig & Exotic & 17 & 556.52 & 83.48 & 640.00 & 320.00 & 1173.32 & 1.17 \\
\hline 20 & Ficus religiosa & Sacred Fig & Native & 15 & 466.34 & 69.95 & 536.30 & 268.15 & 983.21 & 0.98 \\
\hline 21 & Morus alba & White Mulberry & Exotic & 14 & 456.49 & 68.47 & 524.97 & 262.48 & 962.44 & 0.96 \\
\hline 22 & Largestroemia speciosa & Pride of India & Native & 12 & 398.66 & 59.80 & 458.46 & 229.23 & 840.52 & 0.84 \\
\hline 23 & Peltophorum pterocarpum & Copper pod & Exotic & 12 & 241.93 & 36.29 & 278.22 & 1020.15 & 3740.56 & 3.74 \\
\hline 24 & Moringa oleifera & Drumstick tree & Native & 10 & 326.28 & 48.94 & 375.22 & 187.61 & 687.90 & 0.69 \\
\hline 25 & Bauhinia acuminata & Dwarf white orchid tree & Exotic & 10 & 331.99 & 49.80 & 381.79 & 190.90 & 699.95 & 0.70 \\
\hline 26 & Bambusa vulgaris & Bamboo & Exotic & 10 & 254.95 & 38.24 & 293.19 & 146.59 & 537.51 & 0.54 \\
\hline 27 & Syzygium cumini & Jamun & Native & 9 & 296.08 & 44.41 & 340.49 & 1128.00 & 4135.99 & 4.14 \\
\hline 28 & Jatropha Curcas & Jatropha & Exotic & 7 & 232.40 & 34.86 & 267.26 & 133.63 & 489.97 & 0.49 \\
\hline
\end{tabular}




\begin{tabular}{|c|c|c|c|c|c|c|c|c|c|c|}
\hline 29 & Morus rubra & Red Mulberry & Exotic & 6 & 197.01 & 29.55 & 226.57 & 113.28 & 415.37 & 0.42 \\
\hline 30 & Acacia auriculiformis & Earleaf Acacia & Exotic & 5 & 162.32 & 24.35 & 186.66 & 93.33 & 342.21 & 0.34 \\
\hline 31 & Saraca asoca & Sorrowless tree & Native & 5 & 118.61 & 17.79 & 136.40 & 68.20 & 250.07 & 0.25 \\
\hline 32 & Pterospermum acerifolium & Maple-leaved Bayur tree & Native & 4 & 129.22 & 19.38 & 148.60 & 74.30 & 272.44 & 0.27 \\
\hline 33 & Aegle marmelos & Stone apple tree & Native & 3 & 98.48 & 14.77 & 113.26 & 56.63 & 207.64 & 0.21 \\
\hline 34 & Bombax ceiba & Silk cotton tree & Exotic & 3 & 92.07 & 13.81 & 105.89 & 52.94 & 194.12 & 0.19 \\
\hline 35 & Senna siamea & Siamese Senna & Native & 2 & 65.17 & 9.77 & 74.94 & 37.47 & 137.39 & 0.14 \\
\hline 36 & Holoptelea integrifolia & Indian Elm & Native & 1 & 27.06 & 4.06 & 31.12 & 15.56 & 57.06 & 0.06 \\
\hline 37 & Terminalia arjuna & Arjun & Native & 1 & 32.48 & 4.87 & 37.35 & 18.67 & 68.47 & 0.07 \\
\hline 38 & Spathodea campanulata & African Tulip Tree & Exotic & 1 & 32.10 & 4.82 & 36.92 & 18.46 & 67.68 & 0.07 \\
\hline 39 & Psidium guajava & Guava & Exotic & 1 & 27.06 & 4.06 & 31.12 & 15.56 & 57.06 & 0.06 \\
\hline 40 & Cordia myxa & Indian Cherry & Native & 1 & 33.40 & 5.01 & 38.41 & 19.21 & 70.42 & 0.07 \\
\hline 41 & Pongamia pinnata & Indian Beech Tree & Exotic & 1 & 31.73 & 4.76 & 36.49 & 18.25 & 66.90 & 0.07 \\
\hline 42 & Ficus elastica & Rubber Tree & Exotic & 1 & 33.40 & 5.01 & 38.41 & 19.21 & 70.42 & 0.07 \\
\hline 43 & Ficus lyrata & Fiddle-leaf Fig & Exotic & 1 & 33.62 & 5.04 & 38.66 & 19.33 & 70.87 & 0.07 \\
\hline 44 & Magnifera indica & Mango & Native & 1 & 27.06 & 4.06 & 31.12 & 15.56 & 57.06 & 0.06 \\
\hline 45 & Tabebuia argentea & Yellow Trumpet Tree & Native & 5 & 162.32 & 24.35 & 186.66 & 93.33 & 342.21 & 0.34 \\
\hline \multicolumn{3}{|c|}{ Total } & & 1997 & $63,136.81$ & 9470.52 & $72,607.33$ & $38,142.46$ & $139,855.69$ & 139.86 \\
\hline
\end{tabular}




\section{Conclusions}

The present work is a sustainability initiative to inventory the trees of Amity University campus and compute their carbon storage capacity. AGB and BGB were also estimated using the non-destructive method. A total of 1997 trees belonging to 45 different species have been recorded on the campus, with the carbon sequestration potential of 139.9 tons. The ratio of native to non-native species on the campus is approximately 1:1. The results of the study illuminate the value of urban trees, not only as ornamental and aesthetic plantations but also in mitigating the impacts of climate change at a local level. Higher education institutes have an important role in expanding their green cover so as to act as local carbon sinks. It is also imperative that more native species should be planted as compared to the exotic species. The results of the study can be used for future on-campus greening plans, and act as a baseline for future assessments of the campus carbon sink. Such education institutes can model themselves as agents of change and influence student behavior by undertaking such sustainable green practices on campus.

\section{References}

1. Satterthwaite, D.; McGranahan, G.; Tacoli, C. Urbanization and its implications for food and farming. Philos. Trans. R. Soc. B Biol. Sci. 2010, 365, 2809-2820.

2. Indian Infrastructure Report. Infrastructure Development in Low Carbon Economy. 2010. Available online: http://www.idfc.com/pdf/report/IIR_2010_Report_Full.pdf (accessed on 1 August 2020).

3. Ugle, P.; Rao, S.; Ramachandra, T.V. Carbon Sequestration Potential of Urban Trees. In Proceedings of the Lake 2010: Wetlands, Biodiversity and Climate Change, 22-24 December 2010; pp. 1-12.

4. Singh, S.; Bhattacharya, P.; Gupta, N.C. Dust particles characterization and innate resistance for Thevetia peruviana in different land-use pattern of urban area. Int. J. Environ. Sci. Technol. 2018, 15, 1061-1072.

5. Shah, D.R.; Gavali, D.J. Floral diversity in Vadodara gardens, Gujarat, India. Int. J. Conserv. Sci. 2017, 8, 113-120.

6. Strohbach, M.W.; Arnold, E.; Haase, D. The carbon footprint of urban green space-A life cycle approach. Landsc. Urban Plan. 2012, 104, 220-229.

7. Churkina, G. The role of urbanization in the global carbon cycle. Front. Ecol. Evol. 2016, 3, 144.

8. Chang, J.; Qu, Z.; Xu, R.; Pan, K.; Xu, B.; Min, Y.; Ren, Y.; Yang, G.; Ge, Y. Assessing the ecosystem services provided by urban green spaces along urban center-edge gradients. Nat. Sci. Rep. 2017, 7, 11226.

9. Bhalla, P.; Bhattacharya, P. Urban Biodiversity and Green Spaces in Delhi: A Case Study of New Settlement and Lutyens' Delhi. J. Hum. Ecol. 2015, 51, 83-96.

10. Singh, S.; Gupta, N.C.; Bhattacharya, P. Assessment of air pollution responses through biochemical and physical traits observed for four plant species in an urban area. In Climate Change, Resource conservation and Sustainability Strategies; DBH Publishers: Delhi, India, 2017; pp. 32-40.

11. IPCC. 2006 IPCC Guidelines for National Greenhouse Gas Inventories; Eggleston, H.S., Buendia, L., Miwa, K., Ngara, T.; Tanabe, K., Eds.; Prepared by the National Greenhouse Gas Inventories Programme; IGES: Hayama, Japan, 2006.

12. Nowak, D.J.; Crane, D.E. Carbon storage and sequestration by urban trees in the USA. Environ. Pollut. 2002, 116, 381-389.

13. Suryavanshi, M.N.; Patel, A.R.; Kale, T.S.; Patil, P.R. Carbon Sequestration Potential of tree Species in the Environment of North Maharashtra University Campus, Jalgaon (MS) India. Biosci. Discov. 2014, 5, 175-179.

14. Jo, H.K. Impacts of urban greenspace on offsetting carbon emissions for middle Korea. J. Environ. Manag. 2002, 64, 115-126.

15. Gavali, R.S.; Shaikh, H.M.Y. Estimation of Carbon storage in the tree growth of Solapur University Campus, Maharashtra, India. Int. J. Sci. Res. 2016, 5, 2364-2367.

16. Marak, T.; Khare, N. Carbon sequestration potential of selected tree species in the campus of SHUATS. Int. J. Sci. Res. Dev. 2017, 5, 63-65.

17. Nandini, N.; Kumar, M.; Tandon, S. Assessment of Carbon Sequestration in Trees of Jnanabharathi Campus-Bangalore University. J. Ecol. Environ. Conserv. 2009, 15, 503-508.

18. Pragasan, L.A.; Karthick, A. Carbon stock sequestered by tree plantations in University campus at Coimbatore, India. Int. J. Environ. Sci. 2013, 3, 1700-1710.

19. Ahmedin, A.M.; Bam, S.; Siraj, K.T.; Raju, A.S. Assessment of biomass and carbon sequestration potentials of standing Pongamia pinnata in Andhra University, Visakhapatnam, India. Biosci. Discov. 2013, 4, 143-148.

20. Das, M.; Mukherjee, A. Carbon Sequestration Potential, its Correlation with height and girth of selected trees in the Golapbag Campus, Burdwan, West Bengal (India). Indian J. Sci. Res. 2015, 10, 53-57.

21. Ganguly, S.; Das, M.; Mukherjee, M. Carbon Sequestration Potential of phanerophytes used for environmental optimization to mitigate climate change. NeBIO 2017, 8, 197-200.

22. Kour, K.; Sharma, S. Carbon Sequestration Potential of Tree Species in the Premises of Various Educational Institutes, Vijaypur (J\&K), India. Int. J. Res. Environ. Sci. 2016, 2, 40-44. 
23. Saral, A.M.; SteffySelcia, S.; Devi, K. Carbon storage and sequestration by trees in VIT University campus. IOP Conf. Ser. Mater. Sci. Eng. 2017, 263, 022008.

24. Sharma, R.; Pradhan, L.; Kumari, M.; Bhattacharya, P. Assessing urban heat islands and thermal comfort in Noida City using geospatial technology. Urban Clim. 2021, 35, 100751.

25. MacDicken, K.G. A Guide to Monitoring Carbon Storage in Forestry and Agroforestry Projects; Winrock International Institute for Agricultural Development: Washington, DC, USA, 1997.

26. Gilman, E.F.; Watson, D.G. Ficus Benjamina, Fact Sheet ENH 410; Environmental Horticulture Department, Institute of Food and Agricultural Sciences (IFAS), University of Florida: Gainesville, FL, USA, 2007.

27. Gulshan, A. Why the Saptaparni is called the devil's tree. The Hindu, 22 October 2019.

28. Reddy, N.C. Plumeria: world's most beloved garden plant. The Hindu, 29 June 2012.

29. Cox, H.M. A sustainability initiative to quantify carbon sequestration by campus trees. J. Geogr. 2012, 111, 173-183.

30. Haghparast, H.; Delbari, A.; Kulkarni, D.K. Carbon sequestration in Pune university campus with special reference to Geographical Information System (GIS). Ann. Biol. Res. 2013, 4, 169-175.

31. De Villiers, C.; Chen, S.; Zhu, Y. Carbon sequestered in the trees on a university campus: A case study. Sustain. Account. Manag. Policy J. 2014, 5, 149-171. 